\title{
A Deuteronomic Voice in the Joseph Story
}

\author{
Michael Carasik \\ University of Pennsylvania
}

For many years, it has been common to point to the Joseph story, Genesis 37-50, as being fundamentally different from the rest of Genesis "in that its author(s) or redactor(s) brought to their material a superior literary craftsmanship which enabled them to create a single, sustained narrative work whose parts are organically related to one another." "At the same time, it remains easy to detect the traditional J, E, and P sources in the story, as noted (for example) in the Anchor Bible commentary of E. A. Speiser. ${ }^{2}$ It is understandable that these sources could be assembled into a narration like that of Genesis 6-9, where the contradictions about how many of each animal were taken on board and so forth show relatively clearly the seams where previously existing variants of the story were assembled into a single text. But how could these prefabricated pieces be put together to form a work of "superior literary craftsmanship"?

Rather than insisting on single authorship or that preexisting documents have been pieced together, I find it more helpful to think in terms of the concept of "authorial voice." This is a term that is out of favor with scholars of literature. A search of library shelves shows that most dictionaries and encyclopedias of literary terms omit it entirely. Perhaps this is because it is so difficult to define. For example, one reference describes it as "a rather vague metaphorical term by which some critics refer to distinctive features of a written work in terms of spoken utterance ... assessed in terms of tone, style, or personality."3 Yet, as a reader, I find this the most obvious feature of a well-written, distinctive

\footnotetext{
Author's note: I am delighted to be able to offer this essay as thanks to Prof. Tigay, for making a place for me at the University of Pennsylvania and in honor of his contributions to biblical studies.

I. R. N. Whybray, "The Joseph Story and Pentateuchal Criticism," VT I 8 ( I968) 522.

2. E. A. Speiser, Genesis (AB I; Garden City, NY: Doubleday, I964) passim.

3. Chris Baldrick, Oxford Concise Dictionary of Literary Terms (Oxford: Oxford University Press, I99I) 239.
} 
work, and as a writer, I am very well aware of my own authorial voice. A reader with some experience will hear authorial voices of this sort in the Bible as well. Especially in a text like the Joseph story, where it seems evident that earlier materials have been used "to create a single, sustained narrative work," thinking in terms of authorial voice permits a more flexible approach to understanding the text. Ultimately, a specific understanding of the circumstances under which a biblical text was created is still necessary. But it may be helpful to set this aside until a later stage of the inquiry. In what follows, I will examine possible deuteronomic influence on Genesis 37-50 through the lens of authorial voice.

As noted, conventional source criticism divides the Joseph story into passages taken from J, E, and P. Elements of D have also been noted at the end of the story (Gen 50:22-26) — what Joseph Blenkinsopp refers to as "the 'end of an era' schema"4-where the story requires an ending that will link it appropriately to the beginning of the book of Exodus, which follows it narratively and succeeds it in the unified Pentateuch. ${ }^{5}$ Hans-Christoph Schmitt has suggested a broader, Deuteronomistic influence on the book, seen not only throughout the whole ending of the story (chaps. $48-50$ ), but also in chap. 38 , the story of Judah and Tamar. ${ }^{6}$ For Schmitt, it is not merely Genesis and Exodus that had to be linked but the Tetrateuch (Genesis-Numbers) and the Deuteronomistic History (Deuteronomy-2 Kings). A linkage such as this demanded that the roles in the story of Joseph's brother Judah and his sons Ephraim and Manasseh reflect the roles played by the tribes of Ephraim and Manasseh in Israelite history.

4. Joseph Blenkinsopp, "Deuteronomic Contribution to the Narrative in GenesisNumbers: A Test Case," in Those Elusive Deuteronomists: The Phenomenon of Pan-Deuteronomism (ed. Linda S. Schearing and Steven L. McKenzie; JSOTSup 268; Sheffield: Sheffield Academic Press, I999) 92 n. I8.

5. See also Hans Ausloos, who, however, denies that elements resembling "Deuteronom(ist)ic literature" here are necessarily dependent on it ("The Deuteronomist and the Account of Joseph's Death [Gen 50,22-26]," in Studies in the Book of Genesis: Literature, Redaction and History [ed. A Wénin; Leuven: Leuven University Press, 200I] 395). See also idem, "Les Extrêmes se Touchent... . Proto-Deuteronomic and SimiliDeuteronomistic Elements in Genesis-Numbers," in Deuteronomy and Deuteronomistic Literature (ed. M. Vervenne and J. Lust; BETL i33; Leuven: Leuven University Press, 1997) 343-66.

6. Hans-Christoph Schmitt, "Die Josephsgeschichte und das deuteronomistische Geschichtswerk: Genesis 38 und 48-50," in Deuteronomy and Deuteronomistic Literature, $39 \mathrm{I}-405$. 
In fact, as I hope to show, a Deuteronomistic voice can be heard much more extensively in the Joseph story. This voice makes itself known both in deuteronomic language and in a particular deuteronomic attitude that (it seems to me) has been neglected as a tool for discovering deuteronomic influence in other books of the Bible-Deuteronomy's psychological orientation. Focusing on these two elements of how the writer of Deuteronomy sounds, I hope to demonstrate that, despite the origins of the Joseph story primarily in the J, E, and $\mathrm{P}$ sources, the writer who composed it was indeed influenced throughout by a deuteronomic outlook.

\section{Deuteronomic Vocabulary}

It is reasonably easy to show a sprinkling of deuteronomic vocabulary in the Joseph story. One finds, for example, the expression כל־הימים twice in the Joseph story (Gen 43:9 and 44:22). It is found 13 times in Deuteronomy ${ }^{7}$ and nowhere else in the Pentateuch. ${ }^{8}$ Another example demonstrates that the author was in fact consciously imbued with deuteronomic language. Deuteronomy twice employs the idiom חכם ונבון, in precisely that form. The first occurrence is when Moses recounts his instructions to the Israelites to provide men who are "wise and discerning" to help him rule over the people (Deut I:I3). 9 The second is when he is describing what will be the reaction of other nations to the Israelites' system of law: "What a wise and discerning people that great nation is!" (Deut 4:6). The same verse combines the two roots in their nominal forms when Moses tells the Israelites, "Make sure to observe them, for that will be your wisdom and discernment [חכמתכם ובינתכם] in the eyes of the nations who will hear all these laws." Finally, the idiom is found also in the

7. Deut 4:IO, 40; 5:29; 6:24; I I:I; I 2:I; I 4:23; I8:5; I9:9; 28:29, 32; 31:I3; and 33:I 2 .

8. I argue here against Moshe Weinfeld, who says that this phrase "also belongs to the rhetorical clichés of Deuteronomy ... but is too common to be considered as peculiarly deuteronomic" (Deuteronomy and the Deuteronomic School [Oxford: Oxford University Press, I972; repr. Winona Lake, IN: Eisenbrauns, I992] 358 no. I6). Since the other examples he gives are from Samuel and Kings, I think the phrase may indeed fairly be considered deuteronomic, or at least Deuteronomistic. For the present purposes I make no distinction between the two terms.

9. That this expression is explicitly deuteronomic is evident by a comparison with the comparable passage in Exod I 8:2 I, where Jethro advises Moses to seek men of good character rather than men who are wise. See Michael Fishbane, Biblical Interpretation in Ancient Israel (Oxford: Clarendon, I985) 245. 
song of Moses, where (as is common in poetry) it is split in half to make a pair that will balance parallel versets: ${ }^{\text {Io }}$ "If only they were wise [חכמו], they would comprehend this; they would discern [יבינו] their future" (Deut 32:29). The same idiom appears nowhere else in the Pentateuch but in the story of Joseph. He advises Pharaoh to look for "a man discerning and wise [נבוץ וחכם]" (Gen 4I:33) to take control of the country in advance of the coming famine, and Pharaoh acknowledges, "Since God has informed you of all this, there can be no one as discerning and wise [נבוץ וחכם] as yourself" (Gen 4I:39). Seidel's law makes clear that the author is not merely using this phrase but is in fact signaling that he is quoting the deuteronomic idiom. ${ }^{\text {I }}$

The word תועבה 'abomination' demonstrates a similar link between the Joseph story and Deuteronomy, where it occurs 17 times. ${ }^{12}$ In Genesis, it appears only here, when the narrator explains that the Egyptians would find it disgusting to eat with Hebrews $(43: 32)$ and when Joseph tells his brothers to explain that they are shepherds, because this is an abomination to the Egyptians and consequently his brothers would be permitted to dwell autonomously in Goshen (46:34). The occurrence of this word elsewhere in the Bible makes possible a kind of biography of this word as a genetic marker of Israelite intellectual history. It is used even more in Proverbs-a full 20 times. From the realm of wisdom, if Moshe Weinfeld's cogent arguments are indeed correct, it

ıо. In Deuteronomy, if not elsewhere, these words make up a pair of what Adele Berlin has called "conventionalized coordinates" (The Dynamics of Biblical Parallelism [Bloomington: Indiana University Press, I992] 76).

I I. Moshe Seidel, "Parallels between Isaiah and Psalms," Sinai 38 (I955-56) I 49-72, 229-40, 272-80, 333-55; repr. in idem, Hiqrei Miqra (Jerusalem: Mossad Harav Kook, I978) I-97. Avi Hurvitz has called this phenomenon "diachronic chiasm," and identifies it as a characteristic of Late Biblical Hebrew ("Diachronic Chiasm' in Biblical Hebrew" (Hebrew), in Bible and Jewish History [ed. Benjamin Uffenheimer; Tel Aviv: Tel Aviv University, I97I] 248-55 [English abstract on xxv-xxvi]). Pancratius C. Beentjes, apparently unaware of Hurvitz's article, has discussed the phenomenon under the name "inverted quotation" ("Discovering a New Path of Intertextuality: Inverted Quotations and Their Dynamics," in Literary Structure and Rhetorical Strategies in the Hebrew Bible (ed. L. J. de Regt, J. de Waard, and J. P. Fokkelman; Assen: Van Gorcum / Winona Lake, IN: Eisenbrauns, I996) 3I-50. He notes that the phenomenon can be found as well in Egyptian, Greek, and Latin texts from antiquity (46-68). Thanks to Marc Brettler for referring me to this article.

I 2. Deut 7:25; I 2:3 I; I 3:I 5; I 4:3; I 7:I, 4; I 8:9, I2 (twice); 20:1 8; 22:5; 23:19; 24:4; 25:16; 27:15; and 32:16. See Weinfeld, Deuteronomy and the Deuteronomic School, 323 no. I. 
was adopted and transformed by the Deuteronomists. In the Pentateuch, the word is found twice in the Joseph story, as I have shown, and six times in the Holiness Code. ${ }^{13}$ If, as is commonly accepted nowadays in the Jewish-Israeli school of biblical scholarship, the Pentateuch was redacted by $\mathrm{H},{ }^{14}$ the appearance of this deuteronomic word in the Holiness Code is easy to understand. Whether at this point or somewhat earlier, it was also a natural part of the vocabulary of the author of the Joseph story.

A historical sketch of this sort also provides a reasonable explanation for the words in the Joseph story that are not merely absent from deuteronomic language but actually contravene it. There are two clear vocabulary items in the Joseph story that demonstrate that, whatever other similarities we may find, the author of the story uses $\mathrm{P}$ vocabulary as readily as $\mathrm{D}$ vocabulary. The first example is the word אחזה 'portion' or 'inheritance'. This is well known to be characteristic $\mathrm{P}$ vocabulary. In fact, it is part of the evidence for identifying Deut 32:48-52 as P, because it is used in Deut 32:49, as Moses dies, instead of נחלה, the word preferred by D. ${ }^{15}$ The word נחלה is indeed found in the Joseph story, but only once (Gen 48:6), while אחזה occurs four times (Gen 47:I I, 48:4, 49:30, and 50:13).

The other vocabulary opposition that I would like to point out has not yet been mentioned in the literature, to the best of my knowledge. ${ }^{16}$ It is the pair of verbs that Biblical Hebrew uses for the English concept "to refuse." In deuteronomic usage, the Hebrew phrase corresponding to this meaning is לא אבה, 'to be unwilling' or 'to not want to do something', which occurs seven times in the book. ${ }^{17}$ The word preferred for 'refuse' elsewhere in the Pentateuch is מאבר,

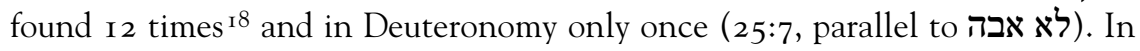
the Joseph story, the deuteronomic phrase does not occur at all, while

I3. Lev I8:22, 26, 27, 29, 30; and 20:13. The word also occurs twice in Exod 8:22, where I do not consider it to be diagnostic of any broader phenomenon.

I4. See, for example, Israel Knohl, who maintains, "[T]he Torah book was edited and shaped in HS [Holiness School] circles" (The Sanctuary of Silence: The Priestly Torah and the Holiness School [Minneapolis: Fortress, 1995] I03).

I5. S. R. Driver, Deuteronomy (3rd ed.; Edinburgh: T. \& T. Clark, I901) 384; and Jeffrey H. Tigay, The JPS Torah Commentary: Deuteronomy (Philadelphia: Jewish Publication Society, I996) 518.

I6. BDB notes "in Hex. rare \& only JED, incl. Lv 26:2 I" (2b, s.v. "I אבה").

I 7. Deut I:26, 2:30, Iо:10, I3:9, 23:6, 25:7, and 29:19. It occurs elsewhere in the Pentateuch only in Gen 24:5, 8; Exod 10:27; and Lev 26:2 I.

I8. Exod 4:23; 7:14, 27; 9:2; I0:3, 4; I6:28; 22:16 (twice); Num 20:2 I; 22:13, and I 4 . 
occurs three times (Gen 37:35, 39:8, and 48:19). The author, then, is a writer who is at home with deuteronomic idiom but is not restricted to it.

\section{Psychological Orientation}

Though the deuteronomic phrase לא אבה does not occur in the Joseph story, it may stand as representative for an aspect of the deuteronomic voice that is, indeed, loud and clear there-the psychological orientation that pervades the book of Deuteronomy. I have discussed this in detail elsewhere, ${ }^{19}$ but I will briefly review it here.

I have referred to Deuteronomy's psychological orientation, but it might not be out of place to phrase it a bit more strongly as "psychological obsession." In contrast with most of the Pentateuch, the Deuteronomist cares not only about what the Israelites do but also about what they think and feel. This may be clearly seen by the fact that Deuteronomy actually decrees laws that demand that the Israelites assume certain psychological states: to love and fear God; to know and to rejoice; not to covet or take pity. Commands of this sortexcept for the psychologically trivial exhortation "do not fear," which is a reassurance more than it is a psychological demand-are found elsewhere only in two places in the Pentateuch: three times in the Ten Commandments ${ }^{20}$ and eight times in the Holiness Code. ${ }^{2 \mathrm{I}}$

Two examples will demonstrate how this psychological orientation manifests itself in deuteronomic writing that, in the hands of another biblical author, would have omitted any reference to the life of the mind. The first is the law distinguishing manslaughter from murder. The thing that identifies one killing as intentional and another as unintentional is, obviously, the intent of the one who did the killing; that is, what he had in mind. Deuteronomy, indeed, frames it this way: "Then Moses set aside three cities eastward across the Jordan to which a killer might flee who killed his fellow unintentionally [בבלידידעת], not having ever borne hatred for him [שנא לו]; he could flee to one of these cities and live" (Deut 4:4I-42; the same usage appears in Deut I9:4). But the comparable laws in Exodus and Numbers do not make reference to the state of mind of the one responsible for the death. They view the process from a point of view external to the mind. Instead of בבלי-דעת 'unintentionally', Num 35:22 uses

19. Michael Carasik, Theologies of the Mind in Biblical Israel (Studies in Biblical Literature 85; New York: Peter Lang, 2005) I 77-2 I5.

20. Exod 20:8 and $\mathrm{I} 7$ (twice).

2 I. Lev I 9:3, I 7, I 8 (twice), 34; 25:1 7, 36, and 43 . 


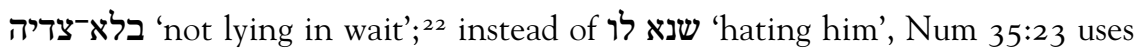
אויב לו 'being his enemy'. They imply that objective examination of the physical circumstances of the death is enough to determine whether or not the killing was accidental. By comparison, it is clear that Deuteronomy is interested in what was going on in the mind of the killer.

It may be argued that the formulation in Exodus and Numbers reflects not a disinterest in the mind but a focus on external details as the only possible objective way to come to some decision about what may have been going on in the killer's mind. But it is precisely this difference in focus that is my point. Deuteronomy is focused throughout on the mind, while psychological aspects of behavior are almost never of concern in the other pentateuchal voices. Another example in Deuteronomy, Deut i 8:9, also illustrates this point: "Do not learn to perform [לא־תלמד לעשות] the abominations of those nations." The words learn to are easy enough to overlook, but what they meant to the Deuteronomist can be seen simply by comparing our verse to Lev i 8:26: "Do not perform any of those abominations." This is a straightforward demand of which, indeed, the Deuteronomist could heartily approve. But from his perspective it is not enough. The avoidance of an external act may simply mean that one doesn't want to (or has been careful enough not to) get caught. But, for the Deuteronomist, the only assurance of correct action is correct thought. One must not merely refrain from the acts, but one must make sure to avoid learning to do them. Again, Deuteronomy threatens that the covenant must not merely be fulfilled but must be accepted "without mental reservation": "Lest there be among you a man or a woman, a clan or a tribe that is turning today from the LoRD your God ... and he assure himself [ו223], I will be all right, though I follow the dictates of my own heart—sweeping away the wet with the dry!" (Deut 29:1 7-18). Deuteronomy therefore focuses, over and over again, not merely on what the Israelites are to do but on what they are to think and feel.

This exact sort of psychological orientation is found in the narrative sections of Genesis-Numbers in (and only in) the story of Joseph. I will start by mentioning the six dreams (Gen 37:5-II, 40:5-19, and 4I:I-7) that are part of the story. Shaul Bar has observed that predictive dreams are understood in the Bible not as psychological phenomena but as symbolic communications from

22. Similarly, Exod 21:13, לא צדה 'he did not lie in wait'.

23. On the translation of התברך בלבבו, see Driver, Deuteronomy, 325; and Tigay, Deuteronomy, 279. 
the deity. ${ }^{24}$ But I would point out that communicative dreams of this sort, even if they do not originate in the mind, do manifest themselves there. The fact that we are dealing not with one dream but with six, in three sets of two that structure the narrative, ${ }^{25}$ is a clue that it is a natural thing for our narrator to make the mental life of his characters part of his story.

There is more vocabulary in the Joseph story that is characteristic of Deuteronomy as well, but its significance lies not merely in this linkage but in the fact that it is used for a particular purpose: to focus on mental activity. In Gen 45:12, we find Joseph trying to convince his stunned brothers of his identity by saying, "Behold, it is your own eyes that see, and the eyes of my brother Benjamin, that it is my mouth which speaks to you." Expressions of this sort-with "your eyes" as the subject of the verb "see"-are so characteristic of Deuteronomy, where they are found nine times, ${ }^{26}$ as to be diagnostic of the deuteronomic voice. The point is not merely the cliché that seeing is believing but that direct perception by the eyes must inevitably force the mind into the correct perspective. In Genesis 45, it is not "I am Joseph" (v. 3) that is the clincher-as the verse continues, "his brothers could not answer him, for they were stunned at him"-but "your own eyes see" (v. I2). Joseph's assumption, lent to him by the author of the story, is that sight must create belief. It is an absolutely deuteronomic perspective. ${ }^{27}$

A comparable deuteronomic idiom involving the eye occurs a bit farther on in this same chapter. Assuring the brothers that a good life awaits them under his patronage, Joseph insists, "Don't worry [ועינכם אל־תחס] about your belongings, for the best of all the land of Egypt will be yours" (Gen 45:20). The idiom is used in a quite different context in Deuteronomy, where it implies merciless extermination. ${ }^{28}$ Nonetheless, the sense of the idiom is very

24. Shaul Bar, A Letter That Has Not Been Read: Dreams in the Hebrew Bible (trans. Lenn J. Schramm; HUCM 25; Cincinnati: Hebrew Union College Press, 200I). His chapter on "Symbolic Dreams" (pp. 44-77) concludes that the biblical writers understood symbolic dreams to come from an external rather than an internal psychological source, as do prophetic dreams. This leaves only "Dreams as Fleeting Experiences" (pp. I 24-32), which points to Isa 29:7-8; Job 20:8; Qoh 5:2, 6; and perhaps Pss 73:20 and I26:I as biblical sources suggesting that dreams are a product of the imagination.

25. See Yairah Amit, "Repetition as a Literary Principle in the Design of the Joseph Story," Teudah 7 ( I 99I ) 55-66, esp. 56-62 [Hebrew].

26. Deut 3:2 I , 27; 4:3, 9; 7:19; I0:2 I; I I:7; 28:32; and 29:2. See Driver, who omits 3:27 and 28:32 (Deuteronomy, lxxxiii, nos. 59-60).

27. See my Theologies of the Mind, I 83-88; and my "To See a Sound: A Deuteronomic Re-reading of Exodus 20: I 5," Proof I9 (1999) 257-65.

28. It occurs five times, in Deut 7:16; I3:9; I9:13, 21; and 25:12. 
much the same: prohibition of concern, an insistence that the mind not be occupied with something that might interfere with the mental state that the one using the idiom wishes his addressee to have. ${ }^{29}$ Again, as with Deut I 8:9 ("Do not learn to perform the abominations of those nations"), had a different narrator simply eliminated this phrase from Gen 45:19-20 (resulting in: "Take wagons from the land of Egypt for your children and your wives, bring your father, and come. All the best of the land of Egypt will be yours"), no reader would have missed it. But the narrator of the Joseph story was oriented toward the life of the mind.

A similar expression intrudes on Jacob's complaint to his sons, as recounted by Judah to Joseph in Gen 44:27. He does not say, "My wife bore me two sons," but rather "You know [אתם ידעתם] that my wife bore me two sons." I also point to the apparently superfluous insistence by Joseph that his brothers "not be grieved [אל־תעצבו] or angry [ואל-יחר בעיניכם]" (Gen 45:5) and that they "do not quarrel [אל-תרגזר]" (Gen 45:24) on the way home. Again, these are psychological references ${ }^{30}$ that would not be missed had they not been included and that would not have been included by a biblical writer who had not adopted the psychological focus of the Deuteronomist. Even the starving Egyptians in Gen 47:1 8 do not tell Joseph, "the money is gone," but rather "we cannot conceal [לא נכחד] from my lord that the money is gone." They are thinking about what he might be thinking.

I turn now to one final aspect of the Joseph story that makes clear that its author had a psychological perspective-the role of remembering and forgetting in the story. The verbs זכר 'remember' and שכח 'forget' are scattered sparsely elsewhere in Genesis, ${ }^{3}$ ' but their usage is comparatively concentrated in the Joseph story:

- Joseph speaks to the butler: "But when things go well with you, remember that I was with you [זכרתני אתך] and do me a favor: remind Pharaoh that I am here [והזכרתני אל-פרעה] and get me out of this place" (Gen 40:I4). Although the Hiphil of זכר ordinarily means 'mention, utter' (NJPsv: "do

29. Again, I disagree here with Weinfeld, who says that לא תחוס עינך "arises from the special context," rather than being specifically deuteronomic, and that "in no case can the occurrence of such phrases in a text be used as evidence of deuteronomic origin" (Deuteronomy and the Deuteronomic School, 2-3).

30. The word רגז 'quarrel' (Gen 45:24) refers not to the objective fact of there being a disagreement but to the disagreement's emotional aspects.

31. זכר: Gen 8:1, 9:15-16, I9:29, and 30:22; שכח: Gen 27:45. 
me the kindness of mentioning me to Pharaoh"), I translate it as "remind," using a word with psychological implications, precisely because of the preponderance in this story of words of remembering and forgetting.

- "But the butler did not remember [לא־זכר] Joseph; he forgot him [וישכחהו]" (Gen 40:23).

- The butler speaks to Pharaoh after the latter, too, has dreamed: "This day, I recall [מזכיר] my sins" (Gen 4I:9). As in 40:I4, NJPsv translates the phrase "I must make mention today of my offenses," but again the word is definitely to be understood as a reference to memory. The butler, while simultaneously reminding Pharaoh of his previous offense, is recalling another offense of his. As Gen 40:23 warned us, he has forgotten to remember Joseph.

- "Then will come seven bad years, when all the abundance in the land of Egypt will be forgotten [נשכח]" (Gen 4I:30).

- "Joseph remembered [ויזכר] what he had dreamed about them" (Gen 42:9).

As with the dreams, these acts of remembering and forgetting are intrinsic to the story. The fact that the butler "recalls" his sin, an expression that is utterly unnecessary for plot purposes, makes this clear. The author is psychologically oriented, so much so that his characters are too. The butler does not simply remember Joseph when the occasion of Pharaoh's dreams calls for it; he announces that he is remembering him.

We may add to this collection Gen 4I:5I, in which Joseph names his first son Manasseh, מנשה, because "God has enabled me to forget [נשני] all my trouble, and my whole family." A comparison with the story of Joseph's father, Jacob, highlights this difference in authorial perspective. We don't know whether Jacob forgot his troubles during his 20 years shepherding Laban's flocks or whether he suddenly remembered when he encountered his brother on the way home that Esau had threatened to kill him, for the writer of the Jacob story does not tell us. But the author of the Joseph story does tell us this, over and over again.

Unlike the authors of the rest of Genesis, unlike the author of the exodus story, the author of Genesis 37-50 shares with the Deuteronomist an interest in the life of the mind. He may not have the Deuteronomist's fierce determination to see that independent thinking is controlled-it could hardly serve his narrative purpose-but the life of the mind is clearly part of his own mental world. One final aspect of the story that may reflect this is Joseph's constant planning. Certainly, the biblical world was full of people working to achieve future success that they had as yet only imagined. But it is hard to think of 
another biblical character who is depicted as being as full of plans as Joseph is. Whether saving Egypt from famine (Gen 4I:34-36), entrapping his brothers (Gen 44:I-5), or prepping his brothers on what to say to Pharaoh in order to arrange the family's move to Egypt as he wished (Gen 46:3I-34), Joseph is full of ideas. They are the outward expression of a character with an inner life. This aspect of the "literary craftsmanship" of the Joseph story has, for me, an unmistakable deuteronomic accent.

Having been sensitized to the deuteronomic voice in Genesis $37-50$, one can begin to hear as well other possible echoes of it that could never have been considered as primary evidence for it. Two more come to mind at the moment. The first is Joseph's amassing all the money (Gen 47:14) and horses (Gen 47:1 7) of Egypt. This could conceivably be a reference to the deuteronomic law of the king, which stipulates (Deut $\mathrm{I} 7: \mathrm{I}^{6}-\mathrm{I} 7$ ) that the Israelites' future king not amass an excess of horses, money, or women. All three are among the flaws of Solomon as described in the Deuteronomistic History (I Kgs IO:I4-I I:5); the women are omitted in the corresponding chapter of the Chronicler's history (2 Chronicles 9) because the Chronicler had a tin ear for the deuteronomic voice and did not understand that the accumulation of horses and money was part of the Deuteronomic Historian's criticism of Solomon here.

The second possible echo is Joseph's outrageous use of the emergency circumstances to transfer all of the agricultural wealth of Egypt (except for the wealth of the priests) into royal hands, charging the people for their own confiscated grain and eventually turning them into slaves (Gen 47:25). From Deuteronomy's well-known humanitarian perspective, ${ }^{32}$ this would be enough to justify the reciprocal future enslavement of Joseph's family by the Egyptians-an enslavement that required explanation by any serious biblical historiographer.

\section{Conclusion}

At one time, it was common to find the hand of the wisdom school in book after book of the Bible. 33 "Today," writes Norbert Lohfink, "a self-respecting doctoral student has to find the hand of a Deuteronomist somewhere in the Bible. This is the only way into the guild." 34 At the risk of earning Lohfink's

32. Tigay, Deuteronomy, xviii.

33. James L. Crenshaw, "Method in Determining Wisdom Influence upon 'Historical' Literature," JBL 88 ( 1969) I 29-42.

34. Norbert Lohfink, "Was There a Deuteronomistic Movement?" in Those Elusive Deuteronomists: The Phenomenon of Pan-Deuteronomism (ed. Linda S. Schearing and Steven L. McKenzie; JSOTSup 268; Sheffield: Sheffield Academic Press, I999) 37. 
scorn, I too have proposed to find a deuteronomic hand-or, as I prefer to characterize it, a deuteronomic voice-in Genesis 37-50. I am aware that the suggestion complicates the literary history of this section of Genesis. It is not my purpose here to solve the conundrum of the composition of the Joseph story, though the reader will no doubt have gathered my own opinion that the author of the story was what may be called "post-documentary" - both chronologically and in the sense that he was not primarily concerned with integrating earlier texts but simply used them as his raw material in the composition of a new version of the story. ${ }^{35}$ It is my purpose to suggest that elements of $\mathrm{D}$ may be found in the Joseph story along with elements of J, E, and P that have long been identified. But these deuteronomic elements occur not just as isolated fragments here or there. Rather, the authorial voice of the Joseph story is thoroughly deuteronomic in at least one respect-his constant attention to the thoughts and emotions of his characters.

35. A possible empirical model for such composition (I allude to one of Prof. Tigay's most important contributions to biblical studies) is Louis Ginzberg's Legends of the Jews (trans. Henrietta Szold; 7 vols.; Philadelphia: Jewish Publication Society, I909-38), a retelling of many rabbinic midrashim in the form of a continuous narrative. 